\title{
White Mango Scale, Aulacaspis tubercularis, Distribution and Severity Status in East and West Wollega Zones, Western Ethiopia
}

\author{
Temesgen Fita
}

Department of Plant Sciences, Wollega University, Post Box No: 38, Shambu, Ethiopia

\begin{tabular}{|c|c|}
\hline \multirow{14}{*}{$\begin{array}{l}\text { Abstract } \\
\text { Mango is attacked by many insect pests which reduce the quality and productivity of the crop. } \\
\text { Among the insect pests attacking mango plant, white mango scale is the most devastating } \\
\text { insect pest. White mango scale, was reported since } 2010 \text { from Guto Gida district of East } \\
\text { Wollega zone. The distribution and severity of white mango scale was studied in selected } 5 \\
\text { districts and } 10 \text { kebeles of East and West Wollega and insect infestation and the degree of } \\
\text { damage. Results of the survey showed that from the sampled five districts white mango scale } \\
\text { distributed to all four districts except Mana Sibu. From the survey it was known that the } \\
\text { maximum distance white mango scale dispersed from Loko Keble (Guto Gida district, which } \\
\text { was assumed to be the source of original infestation) was } 67 \mathrm{~km} \text { to the West and } 58 \mathrm{~km} \text { to the } \\
\text { East direction. Distribution and severity status comparisons between sampled districts and } \\
\text { administrative kebele's for the formation of clusters of white mango scale per leave per } \\
\text { mango showed significant difference at } P=0.05 \text { indicating different pest status in the study } \\
\text { areas. Moreover, yield data before and after mango scale appearance showed high } \\
\text { significant difference. From the current survey it was found that white mango scale is } \\
\text { becoming the most important limiting factor for mango production in Western Ethiopia. The } \\
\text { dispersal rate is alarming indicating that within a short period of time the pest can invade the } \\
\text { whole of Western Ethiopia particularly Wollega zones. Hence, due attention should be given } \\
\text { to this pest, so that ecologically friendly management options will be made available for the } \\
\text { mango growers in that part of the country in particular and Ethiopia in general. }\end{array}$} & \\
\hline & \\
\hline & necervea : $15-04-\angle 014$ \\
\hline & $\begin{array}{l}\text { Revised }: 21-08-2014 \\
\text { Accepted : 05-09-2014 }\end{array}$ \\
\hline & \\
\hline & \\
\hline & ormation \\
\hline & \\
\hline & \\
\hline & \\
\hline & \\
\hline & \\
\hline & \\
\hline & \\
\hline
\end{tabular}

\section{INTRODUCTION}

Among the fruits cultivated in Ethiopia mango is preceded in importance only by banana Its area of production in hectare is 3,392.72 (Oromia), 3467.36 (SNNP), 849.7 (Benishangul Gumz), 213.31 (Amahara), 236.88 (Gambella), 21.75 (Dire Dawa) and 86.30 (other parts of Ethiopia) totaling 8,268 (CSA, 2009/2010).

Western Ethiopia, particularly the two zones (East and West) of Wollega, of Oromia regional state, which is located in the upper Blue Nile valley, is suitable for the production of mangoes. It was estimated that $28 \%$ of the mangoes sold in the capital Addis Ababa, were grown in the western region of the country (WAFC, 2006 and Beniam, 2010).

Mango plant suffer from a number of pests at all stages of development i.e. right from nursery stage to grown-up tree stage. Even fruits at pre-harvest stages are affected making them unsuitable for marketing and export (Brown, 1992). In Ethiopia, mango is attacked by many insect pests. Among the insect pests attacking mango fruit are beetles, fruit flies, seed weevil and termites. Moreover, various scale insects, red-banded thrips, and mango tip-borer insects also attack the mango fruit (Jackson et al., 1985).
In East Wollega Zone until 2010 there was no reported insect pest attack on mango plant. In December 2010, white mango scale, was reported from the low land areas of East Wollega zone. In as a diseases as the symptoms were drying of leaves and die-back of twigs. Expertise team report later confirmed that the pest was white mango scale which is a new pest for the locality. The pest attack was first seen on the mango farms of Green Focus Ethiopia LTD and expanded to the neighboring farmers' mango plants. Immediately after the emergence of the pest it has spread to the adjacent administrative kebeles of low land mango producing areas of Guto Gida district in the Anger Valley. The insect infested at all stages of mango plants including improved varieties at Green Focus Ethiopia causing yellowing and drying of leaves, leaf drop and die-back of twigs. Blackburn (1984) and Miller (1990) confirmed and reported white mango scale insect resulted in low mango productivity.

The introduction, establishment, distribution and control practices of white mango scale in east and west Wollega areas have not yet been studied. Therefore, this research was initiated to study the distribution and severity status of white mango scale in east and west Wollega zones. 


\section{MATERIALS AND METHODS}

\section{Description of the Study Area}

The study was carried out in Western Oromia specifically at the major mango production sites of East and West Wollega zones. The two Wollega zones, East and West Wollega, are located at $328 \mathrm{~km}$ and $441 \mathrm{~km}$, respectively, from Addis Ababa to the West.

The study areas in East and West Wollega zones are stratified into three agro ecological zones based on agroclimatic conditions namely: East Wollega Zone ; low land $56.4 \%(1200-1799 \mathrm{~m})$, mid land $28.2 \%(1800-2450 \mathrm{~m})$, and high land $15.4 \%(2460-3178 \mathrm{~m})$ and West Wollega Zone; low land 19.1\% (1100-1700 m), mid land $78.4 \%$
Sci. Technol. Arts Res. J., July-Sep 2014, 3(3): 01-10

$(1800-2200 \mathrm{~m})$, and high land $2.5 \%(2300-2850 \mathrm{~m})$. The major rainy season is during the months of June to September which is the case for many Ethiopian highlands (data obtained from ZAO, DAO and personal communication, Sep 2011).

The study areas, East Wollega (Capital city, Nekemte is located at $9^{\circ} 06^{\prime} \mathrm{N} ; 36^{\circ} 31^{\prime} \mathrm{E}$ ) and West Wollega (Capital city, Gimbi is located at $9^{\circ} 09^{\prime} \mathrm{N} ; 35^{\circ} 51^{\prime} \mathrm{E}$ ), are characterized by dry season (winter) and wet season (summer), where the rainfall varies from 1200 to 2400 $\mathrm{mm}$ and 1100 to $2450 \mathrm{~mm}$, and the annual mean temperature varies from 16.8 to $29.1^{\circ} \mathrm{C}$ and 18 to $32{ }^{\circ} \mathrm{C}$ respectively (Figure 1 and 2 ).

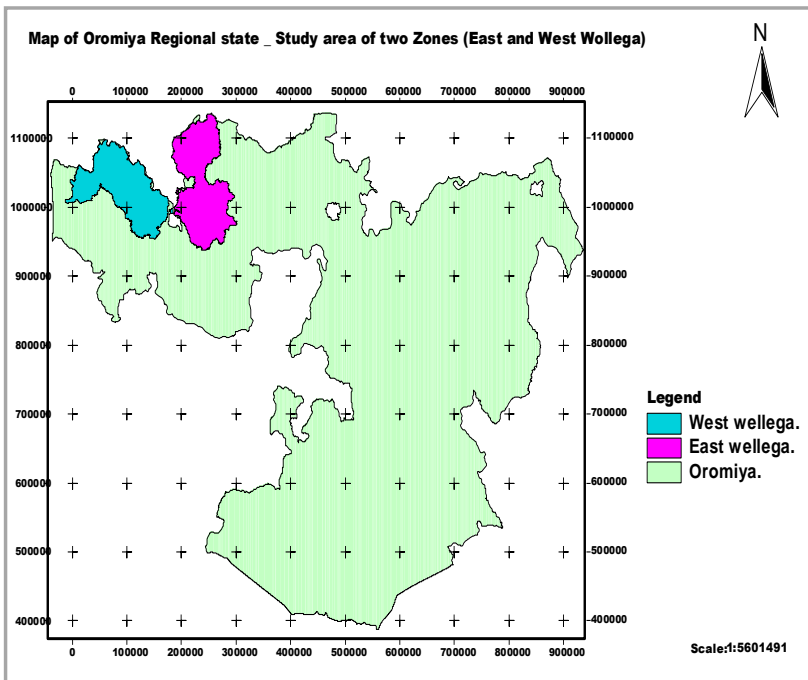

Figure 1: Map of Oromiya Regional State

\section{Type and Sources of Data}

Both relevant qualitative and quantitative data were collected from primary and secondary sources. The primary data for qualitative study were collected from farmers who have adequate knowledge and information about the past and present mango production and pest status of the study area. The knowledge and information of these people include; area under production by fruit crops especially mango fruit, mango seedling sources, annual income from mango fruit before and after the emergence of white mango scale insect, knowledge on white mango scale and management practices of the farmers started if any, other insect pests and diseases attacking mango, if there are natural enemies attacking white mango scale and its managements and institutional support. The primary data were collected from sampled household farmers. Secondary data for quantitative study such as description about the study area, location, topography, climate, population, agricultural production, fruit production activities, and others data were collected from unpublished documents of Zone and District Agriculture offices.

\section{Method of Data Collection and Sampling Procedures}

For this study two Zones and five districts were selected based on their mango production and their geographical location. The districts were also selected purposively and nested design was used. Two administrative kebeles from each district $(5 \times 2=10$ kebeles in total) were purposively selected and surveyed. From each study administrative kebeles twelve mango grower households, totally one hundred twenty farmers were
Map of Research area on both East and West Wollega Zones

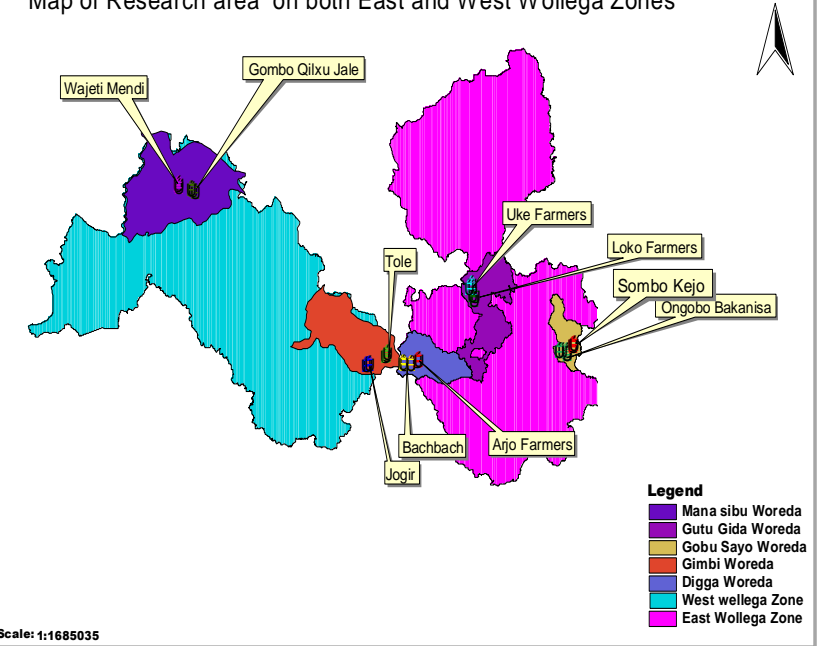

Figure 2: Map of the research area

purposively selected for the study based on the amount of mango and experience they have on mango production. From each administrative kebeles based on the agro ecology of the study area three sites totally thirty sites were selected purposively and the degree of infestation of white mango scale on leaves of mango plant was recorded.

Mango production in west Ethiopia is annual. It occurs once in a year and the peak harvest is in March and May. Hence, data for the study was collected before the time of mango harvesting season, which falls between December and February. Through structured questionnaires, by posing direct and information seeking open ended questions to the interviewers, qualitative and quantitative data were collected from the farmers. Information about the emergence and distribution of the insect pests, damage level and management practices of farmers, past and present situation of the pest, etc was collected by focus group discussion with the sample mango growers. The researcher and five enumerators collected all these data until the end of the field work. From each sites five mango trees, heterogeneous in size and age, were selected randomly and marked at each site for the present study. From each sample site of study areas with in administrative kebeles samples consists of 50 leaves (10 leaves per tree) were collected randomly from middle canopy of mango tree. Then by counting the clusters of white mango scales formed on leaves, the infestation and the degree of damage was recorded by using a scoring method from $0-5$ scale, where; $0=$ none/free from pest attack, $1.0-1.99=$ moderately resistance, $2.0-3.99=$ 


\section{Temesgen Fita}

moderately susceptible, 4.0-5.0 = susceptible and, greater than $5=$ very susceptible, based on damage of leaf parts of mango tree. Williams et al. (2009), used rating scales of pest infestation on mango as; minimal damage $=5-24 \%$ of the panicle destroyed, moderate $=25-50 \%$ damage, severe $=51-70 \%$ damage and very severe $=71-100 \%$ damage. In this case the rating can be related to each other as: $1.0-1.99=5-24 \%, 2.0-3.99=25-50 \%, 4.0-5.0=$ $51-70 \%$ and $>5=71-100 \%$ damage.

In addition secondary data were collected from zone and district agricultural offices. The distribution and severity of white mango scale was studied in selected thirty sample sites.

\section{Data Analysis}

The data collected were subjected to statistical analysis like; descriptive statistics mean Comparisons, and GLM (general linear model) using SPSSv16 computer software. The severity of the pest and its distribution in the study areas was tested by counting clusters of white mango scales formed on mango leaves and analyzed by SAS v 9.00 computer soft ware and the mean, standard error, standard deviation and LSD for mean separation was used at $0.05 \%$ significance level.

GPS was used to record the coordinates and GIS software was used to map the study sites and the infestation.

\section{RESULTS AND DISCUSSION}

\section{Practices and Activities of Farmers on Mango Production}

Data obtained from survey shows that mango plant is grown both at the backyard and in the farm field and a few of them grow at the river bank. Most of the growers produce their mango by rain fed and a few of them grow with supplementary irrigation. From a total of 120 mango producing sample farmers $112(93.3 \%)$ grow their mango by rain fed at the time of the survey, while the rest 8 $(6.7 \%)$ farmers grow both by rain fed and irrigation. From the grower farmers $50(41.7 \%)$ of them grow their mango both at the back yard and in the farm field, while 46 $(38.3 \%)$ of them grow their mango only at the back yard and $24(20 \%)$ them grow their mango in all places mentioned above. The growers or farmers were all native and their age range from 43 to 78 years, in which farmers more than 58 years old account more than $80 \%$.

\section{Importance of Mango Production and Area Owned by Individual Growers \\ Utilization of Mango \\ From 120 sampled respondents, $97(80.8 \%)$ of the growers produce mango for income generation, home consumption, shading, animal feed (fruits), fire wood and fencing material. Twenty one (17.5\%) of the growers produce mango for home consumption, income generation, shading, animal feed, fire wood and for fencing material. The remaining $2(1.7 \%)$ of the growers produce mango for shading, home consumption, income generation, animal feed, fire wood, and for fencing material.}

Sci. Technol. Arts Res. J., July-Sep 2014, 3(3): 01-10

Area Cultivated by Mango in the Study Areas of East and West Wollega zones

According to field observations by the researcher and data obtained from the study area under mango production the number of mango trees owned by individual farmers varies from small to large area. In mango growing areas the average land holding on farmer's field ranges from 0.01- 0.125 ha. Exceptionally from the sampled farmers there were a few farmers who owned 3 to 20 ha of mango. The area of mango owned by individual respondents were randomly measured and converted to hectares. For more accuracy the distance between plants and rows were measured and the number of mango tree found in individual farmers was converted to hectares. The distance between mango plants was seven to ten meters with 8.5 meter mean.

From the data computed about $52(43.3 \%)$ of the growers individually have $0.01-0.125$ ha of mango. The rest $16(13.3 \%), 18(15 \%)$ and $9(7.5 \%)$ of them have $0.156-0.2, \quad 0.21-0.3$ and $0.31-0.4$ ha. of mango, respectively. Exceptionally 8 growers own 3-20 ha of mango individually. The respondents wealth status ranges from poor to wealthier, in which $7(5.8 \%)$ farmers were poor, $83(69.2 \%)$ were medium and $30(25 \%)$ were rich and model farmers.

\section{Source of Mango Seed/seedling}

Observations during the survey showed that the type/cultivar of mango grown by small holder farmers was old-aged type which was planted out from seedlings of unknown varieties Observation of these plantings indicated that mango is well adapted to a fairly wide range of local conditions. Due to its large canopy and ever greenness mango plant helps human beings and animals as a shade plant. People of the lowland locally named it as a "tent". Its height is approximately $15-20$ meters above the ground and most of its branches are crowded. The ripe fruit was harvested by hand and clip them off with the long stalk.

Data obtained from field survey showed that 21 $(17.5 \%)$ of the producers get seedlings from local market and $38(31.7 \%)$ of them get seedlings in combination from market, friends/neighbors and own seed source. About 18 (15\%), $10(8.3 \%)$ and 9 (7.5\%) of them get the seed from neighbors, local market and own seed; local market and own seed only and from local market and neighbors, respectively.

\section{Farmers Knowledge on White Mango Scale}

Data obtained showed that infestation by mango fruit fly, mealy bug, and flower beetle and mango mosquito rarely occurred in the study areas. Others like red-banded thrips, and mango tip-borer insect infestations were not important all the time (Jackson et al., 1985).

Data analysis from the study (Figure 3 ) showed that out of the sampled 120 respondents $74(61.67 \%)$ of them did not know the name and type of the mentioned insect pest. Only respondents nearby Guto Gida district have a little information about this insect pest. From the sampled farmers 80 percent of them gave their idea as the pest is new for the locality. 


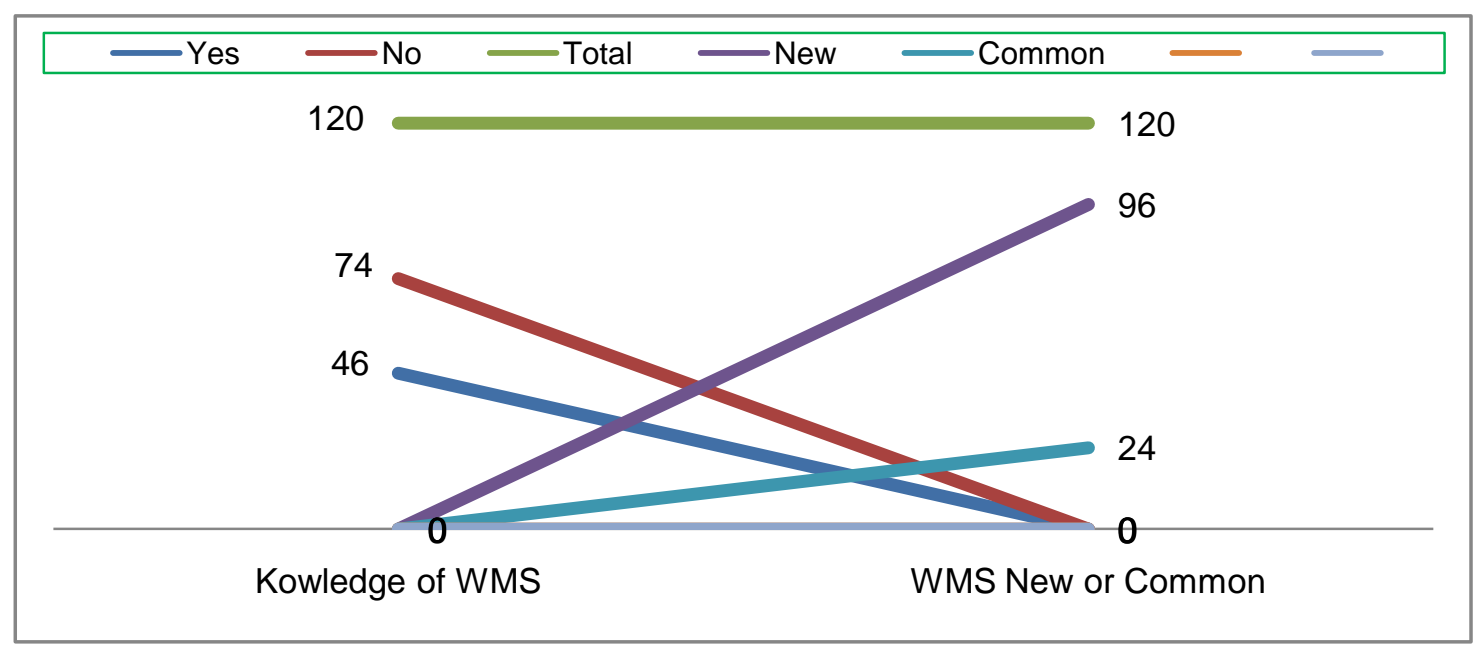

Figure 3: Knowledge of farmers on white mango scale

\section{Distribution or Spread of White Mango Scale}

The researchers and expertise team report that came from Federal Ministry of Agriculture and National Research centre to identify type of insect pest attacking mango plant revealed that the insect pest was white mango scale insect which is a new insect pest for the locality and even for the country. Timothy (2006) indicated that spatial distribution of populations is influenced to a considerable extent by anthropogenic activities that determine landscape structure and introduce (intentionally or unintentionally) commercial and pest species to new regions. Based on this idea it was suspected that white mango scale was introduced from India when Green Focus Ethiopia LTD mango commercial farm was established at Loko administrative kebele and introduced a variety called 'Alphonso' to its new farm. During field survey, farmers in the neighborhood of Green Focus mango farm land witnessed, for first time this insect pest on Green Focus mango plant and after a while it spreads to adjacent old cultivar mango plantations of the local farmers.

Before conducting the actual survey preliminary information was gathered by the researcher from mango growing districts of East Wollega Zone. Preliminary survey result indicated that white mango scale was spread from its original infestation area to all mango growing neighboring districts of the zone like Sasiga, Gida Ayana, Limu, Diga, Sibu Sire and Gobu Sayo of East Wollega Zone mango growing districts to the East, North, West and South directions.
Flight capacity contributes enormously to insect ability to disperse. Insects dispersing in any direction have a higher probability of contacting larger patches than smaller patches. White mango scale is a very small insect; less vigorous individuals tend to colonize more proximal habitats as compared to more vigorous individuals which can fly greater distances and colonize more remote habitats. Even though the emergence of white mango scale at Loko administrative kebele, Guto Gida district of East Wollega Zone, accounts about one and half of a year its distribution was rapid.

Result of the actual survey showed that, from the sampled five districts, white mango scale, reached and covered all mango growing areas of the four districts of Guto Gida, Diga, Gobu Sayo and Gimbi districts except Mana Sibu (Gombo Kiltu Jale and Wajati Mendi having 163 and $170 \mathrm{~km}$ air distance respectively from the source). Within one and half year duration the pest moved little from the place of its first emergence, Loko kebele of Guto Gida district.

Data obtained using GPS and computed by GIS software showed (Table 1) that the maximum air distance covered by white mango scale was $67 \mathrm{~km}$ to the West (Gimbi district- Jogir kebele), and $58 \mathrm{~km}$ to the East (Gobu Sayo district-Sombo kejo kebele), on the way to Finfine from Nekemete. Table 1 showed the start point and arrival of white mango scale in the study area.

Table 1: White mango scale distribution from its original infestation across districts and kebeles in km (air distance)

\begin{tabular}{|c|c|c|c|c|c|}
\hline \multicolumn{6}{|c|}{ White Mango Scale Distribution from the Place of $1^{\text {st }}$ Emergence to the other Study Areas } \\
\hline \multicolumn{2}{|c|}{ WMS Insect Original Infestation Place } & \multicolumn{4}{|c|}{ WMS Distribution/arrival to Districts and Kebeles } \\
\hline Adm. kebele & District & Direction & District & Kebele & $\begin{array}{l}\text { Distribution-air } \\
\text { Distance in km }\end{array}$ \\
\hline Loko kebele & Guto Gida & North & Guto Gida & Uke-Farmers & 6.5 \\
\hline “ “ & & To the West & Diga & Arjo-Farmers & 45 \\
\hline “ & & “ & Diga & Bachbach & 51 \\
\hline " & & " & Gimbi & Tole & 57 \\
\hline “ & & “ & Gimbi & Jogir & 67 \\
\hline “ & & To the East & Gobu Sayo & Ongobo & 56 \\
\hline “ & “ & " & Gobu Sayo & Sombo Kejo & 58 \\
\hline " $\quad$ " & “ & To the West & Mana sibu & Wajati Mendi & ** \\
\hline " $" ~ " ~$ & “ & " & Mana sibu & Sombo kiltu & ** \\
\hline
\end{tabular}

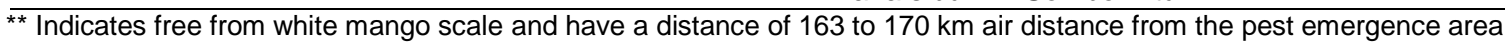
WMS $=$ White Mango Scale 


\section{Temesgen Fita}

From this table it can be concluded that white mango scale is becoming the most important limiting factor of mango production in the study area, even in the western part of the country. The dispersal rate is alarming indicating that within a short period of time the pest can invade the whole mango growing areas of western part of Ethiopia particularly Wollega zones.

\section{White Mango Scale Distribution and Severity Status}

\section{Severity status of white mango scale within the districts}

Severity status of $A$. tubercularis in mango orchards was studied in five districts of two zones: Guto Gida, Gobu Sayo and Diga districts of East Wollega and Gimbi and Mana Sibu districts of West Wollega Zone in the western part of Oromia Regional State. To indicate severity status of white mango scale, even though the twigs and the fruits of mango were attacked by this insect pest, for simplicity only clusters formed on leaves were counted. Data analysis from the survey showed that the severity of the pest in the infested districts varied from moderate to high infection.

\section{Guto Gida District}

From the data obtained clusters formed by white mango scale per leaf indicated that the highest peak occurred at Uke administrative kebele which records a mean value of 10.3 clusters per leaf. Two high peaks occurred, for Uke administrative kebele at site number three sampled mango tree number one and for Loko administrative kebele at site number three sampled mango plant number four which accounted for a mean value of 10.3 and 6.2 clusters of white mango for Uke and Loko kebele, respectively. The least clusters recorded was at Loko administrative kebele at site number two, sampled mango plant number three which had a mean value of 0.1 clusters per leaf. It is the site near by Green Focus Ethiopia LTD, exercising chemical control methods for the pest. The highest peak count of clusters per mango plant per leaf occurred at Uke administrative kebele which recorded 18 clusters per leaf at site number three for sampled mango plant number five. Likewise, at Loko administrative kebele at site number two for sampled mango plant number three, out of the 10 sampled leaves per plant, nine leaves had no scales.

\section{Gobu Sayo District}

The district agricultural office workers and farmers were not aware of this insect pest until this research survey was made in the first week of January 2012. Some farmers and agricultural office workers heard and saw the pest name and type when the survey was carried.

Data obtained from the survey revealed that the highest peak average clusters of white mango scale formed per leaf occurred at Ongobo Bakanisa administrative kebele which had a mean value of 7.4 clusters of white mango scale per leaf. Two high peaks occurred for both administrative kebeles at site number three of Ongobo Bakanisa and site number three of Sombo Kejo administrative kebele which had a mean value of 7.4 and 5.8 clusters per leaf respectively. The least clusters recorded were 0 . clusters per leaf at Sombo Kejo administrative kebele at site number one sampled mango plant number two and site number two sampled mango plant number three. The highest peak count of clusters of white mango scale per mango per leaf occurred at Ongobo Bakainsa administrative kebele at
Sci. Technol. Arts Res. J., July-Sep 2014, 3(3): 01-10

site number three for sampled mango plant number three which counts 13 clusters of white mango scale per leaf. Likewise, out of 10 sampled leaves per five plant, zero clusters per mango per leaf occurred at Sombo Kejo administrative kebele, which were zero clusters of white mango scale per 10 leaves at site number one for sampled mango number two, four and five; and zero clusters for 10 leaves at site number two for sampled mango plant number two and four.

\section{Diga District}

Data obtained from the survey revealed that the highest peak count of clusters of white mango scale formed per leaf occurred at Arjo-farmers administrative kebele which has the mean value of 10.2 clusters of white mango scale per leaf. Two high peaks occurred, for Arjofarmers administrative kebele at site number three sampled mango plant number three and for Bachibach administrative kebele at site number two sampled mango plant number four which showed mean value of 10.2 and 10.1 clusters respectively. The highest peak count of clusters per mango plant per leaf occurred both at Arjofarmers and Bachibach administrative kebele which accounted 15 and 18 clusters of white mango scale per leaf respectively. At Arjo-farmers site number one and sampled mango plant number five and at site number three sampled mango tree number three and five 15 clusters each per leaf were observed. Likewise, at Bachibach kebele site number two for sampled mango plant number four and five each of them accounted 18 and 17 highest peak count of clusters of white mango scale per leaf, respectively. In this study area the least average clusters of white mango scale was recorded at Bachibach administrative kebele at site number one, sampled mango plant number four whish has a mean of 4.0 clusters per leaf.

In this district out of the 10 sampled leaves per five trees, no zero count of clusters of white mango scale occurred. The lowest counts were at Bachibach administrative kebele, which has one cluster of white mango scale at site number one for sampled mango plant number one and three, and at site number three for sampled mango plant number four.

\section{Gimbi District}

Data obtained showed that the highest peak mean clusters of white mango scale per leaf occurred at Jogir administrative kebele with the mean value of 14.1 clusters per leaf. Two high peaks of clusters occurred in this study areas for Jogir administrative kebele at site number three sampled mango plant number one and for Tole administrative kebele at site number one sampled mango plant number two 14.1 and 8.9 clusters of white mango scale per leaf were recorded, respectively.

In the sampled area the least mean clusters recorded were 2.1clusters per leaf at Jogir administrative kebele at site number three, sampled mango plant number three. The highest peak count of white mango scale clusters per sampled mango plant per leaf occurred at Jogir administrative kebele which showed $100 \%$ coverage of clusters per leaf. At Jogir administrative kebele site number one sampled mango tree number one from the sampled 10 leaves 2 were covered $100 \%$ by clusters of white mango scale. Likewise at Tole administrative kebele, at site number one sampled mango plant numbers two had 15 clusters of white mango scale per leaf. 


\section{Temesgen Fita}

At Tole administrative kebele out of the 10 sampled leaves per tree, from site number two sampled mango plant number one, two sampled leaves had zero clusters and from sampled mango tree number three out of 10 sampled leaves one sampled leaf had zero clusters of white mango scale. Likewise at Jogir administrative kebele out of 10 sampled leaves per plant, at site number three sampled mango plant number three, 4 leaves had zero clusters and at sampled mango plant number five of the sampled 10 leaves 1 leaf had zero clusters. The lowest number of clusters was counted at Tole
Sci. Technol. Arts Res. J., July-Sep 2014, 3(3): 01-10

administrative kebele, which counts one cluster per leaf at site number two for sampled mango plant number two and three, and at site number three for sampled mango plant number one and three. With the same procedure at Jogir administrative kebele site number one sampled mango plant number two, of the sampled 10 leaves only one leaf had one cluster and the rest more than two clusters.

Figure 4 ( $a$ and $b), 5$ ( $a$ and $b), 6(a$ and $b)$ and 7 ( $a, b$, $c$ and d) shows Severity status of White Mango Scale in the study area

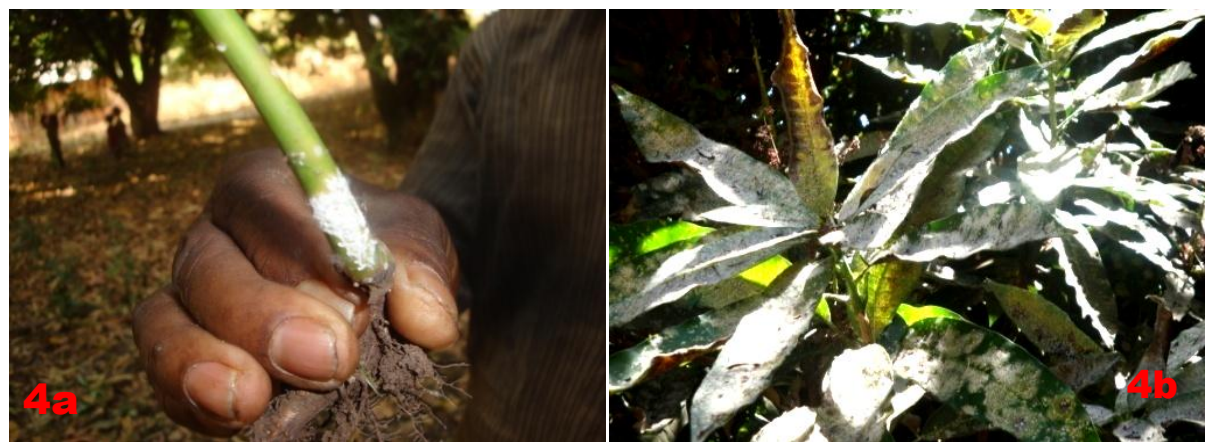

Figure 4 ( $a$ and $b$ ): Seedling and leaves of mango attacked by white mango scale (Gimbi district-Tole Kebele)

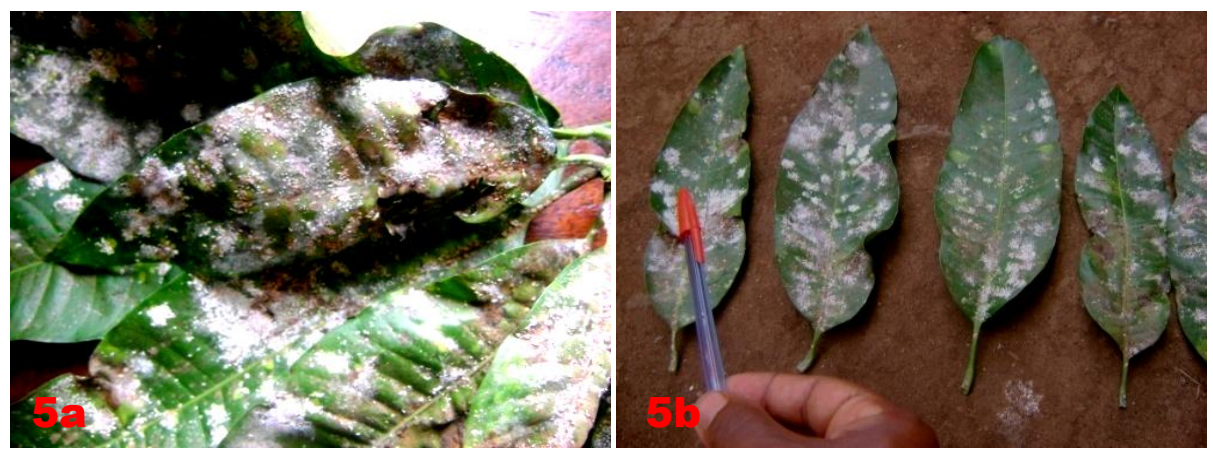

Figure 5 (a and b): Rating mango leaves attacked by white mango scale (Guto Gida district-Uke Kebele)

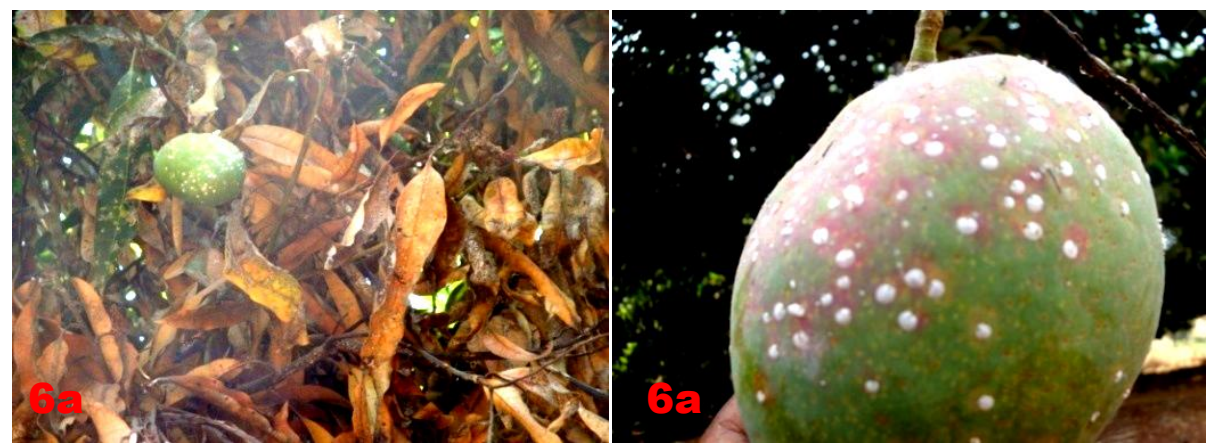

Figure 6 ( $a$ and $b)$ : Mango leaves, twigs and fruits attacked by white mango scale
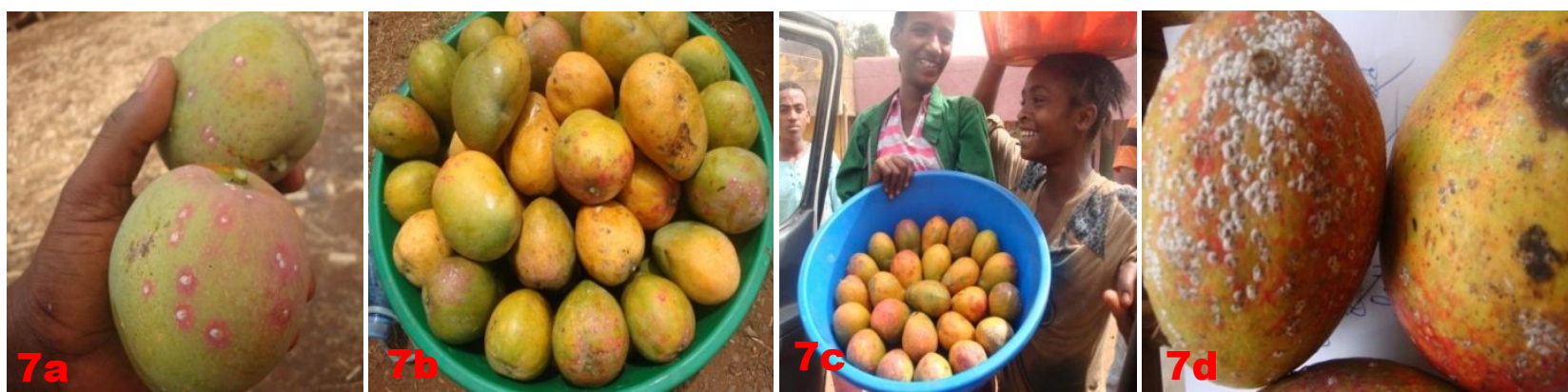

Figure 7 (a, b, c and d): Mango fruits on market attacked by white mango scale (Diga District-Arjo Farmers Kebele). 


\section{Mana Sibu District}

Data obtained from the sampled two administrative kebeles of Mana Sibu district showed that mango plant in the study area was not infested by white mango scale. From the survey it was seen that within one year and three months this insect pest spread to about $67 \mathrm{~km}$ to the west and $58 \mathrm{~km}$ to the east air distance from point of original infestation, Loko administrative kebele. Mana Sibu district has left only 96 to $103 \mathrm{~km}$ air distance from the last white mango scale infested area (Jogir administrative kebele which was $67 \mathrm{~km}$ air distance from the point of original infestation (Loko kebele - Guto Gida district). Since the pest moves with the help of external forces like wind, birds and insect pests it can be assumed from the trend of pest dispersion, that the insect pest may infest Mana Sibu district and other mango growing areas within a short period of time.

\section{Distribution and Severity Comparisons between Sampled Districts and Administrative Kebeles \\ Distribution and Severity Comparisons between Districts \\ As white mango scale first emerged in Guto Gida} district, Loko administrative kebele, it is true that the chance of the adjacent districts or kebele's to be infested by this pest is high, since white mango scale can move with the help of external forces like wind, birds and insect pests (Greathead, 1990 and 1997). The survey revealed that from the sampled five districts except Mana Sibu, white mango scale invaded all mango growing areas of Guto Gida, Gobu Sayo, Digga and Gimbi districts. From the point of original infestation areas of Loko kebele (Guto Gida district) and the infested areas of Gimbi district to Mana Sibu about four districts were located along the way to Mana Sibuu and the absence of the pest in Mana Sibu district might be due to its geographical location i.e. it is far from the infested areas of the last district (Gimbi district). The study areas of Gimbi district, especially Tole and Jogir administrative kebeles were naturally bounded by mountainous highland covered with different species of forest plantation, which might trap the white mango scale insects moving with the help of wind. As to the researcher's assumption, white mango scale movement by wind might be blocked by these natural or physical barriers.

The survey revealed that clusters of white mango scale formed per leafs per mango plant had statistically high significant differences between sampled districts which have a mean value of 4.44 . For zero or no clusters of white mango scale formation there was no significant difference between Guto Gida and Gobu Sayo districts which had a mean value of 1.87 and 1.77 respectively, but there was a significant $(P<0.0001)$ difference between the former mentioned two districts and the rest three (Diga, Gimbi and Mana Sibu) districts, which had mean values of $0.3,0.07$ and 0.00 . For the formation of 1 to 2 clusters per leaf there was significant difference $(P<0.0001)$ between Gobu Sayo and Guto Gida districts which had mean value of 2.57 and 1.4, respectively. There were no significant differences $(P<0.0001)$ between districts of Gimbi and Diga which had mean value of 0.53 and 0.20 respectively. There was also a significant difference $(P<0.0001)$ between all sampled districts for the formation of greater than 2 to 4 clusters of white mango scale with a mean value of 2.27, 1.4, 1.1, 0.87 and 0.00 for Gobu Sayo, Diga, Guto Gida, Gimbi and Mana Sibu districts respectively. Likewise, for cluster formation greater than 4 - 5 there was significant difference between Diga and the rest of the districts with a mean value of 2.23 and 1.43,1.33, 1.2 and 0.00 mean value for Diga , Guto Gida, Gimbi, Gobu Sayo and Mana Sibu districts respectively. For the formation of greater than 5 clusters of white mango scale formation, there was a significant difference between all sampled districts. From this result it was concluded that Gimbi district was the most infested one when compared to the others and Diga, Guto Gida and Gobu Sayo took the next rank.

Table 2: Mean square and standard error of white mango scale severity in East and West Wollega

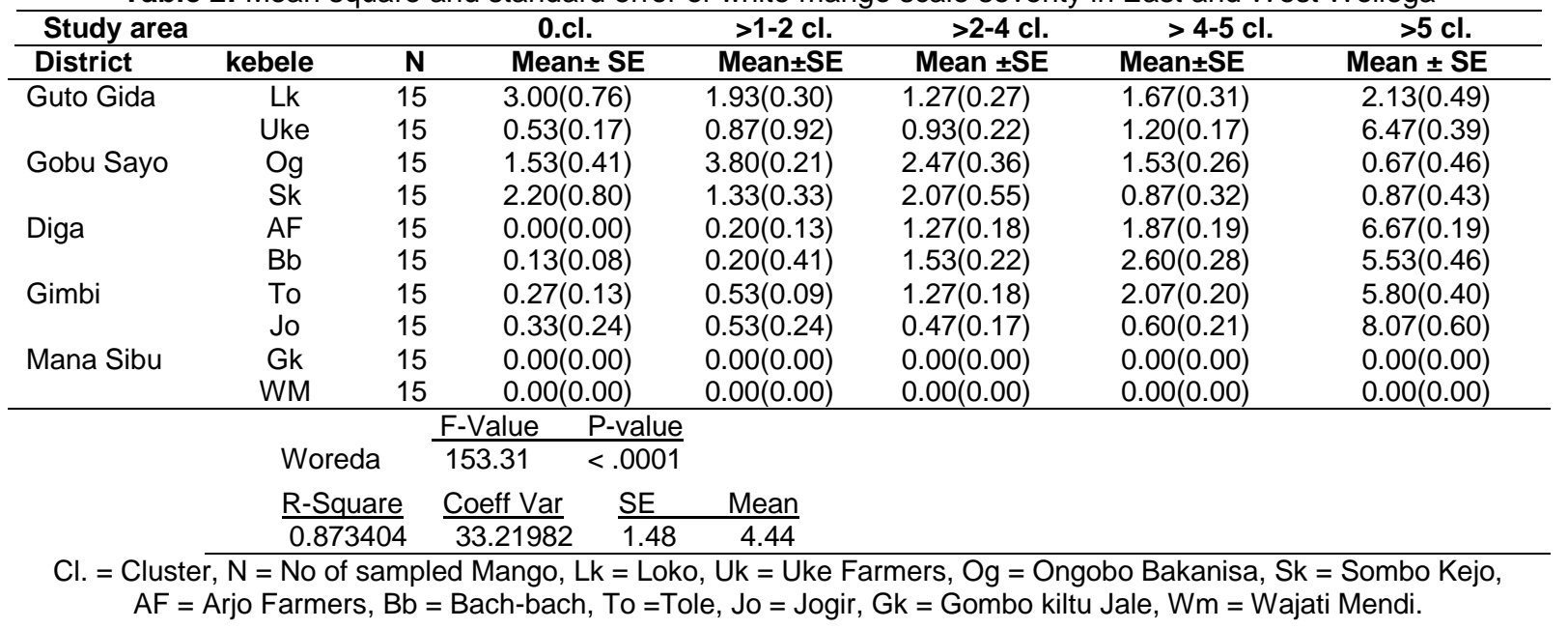

In addition to Table 2, Figure 8 demonstrated the variations among districts in terms of white mango scale infestation. According to figure 4 Gimbi District had more severity and Gobu Sayo had less severity.

\section{Estimated Mango Yield Losses Due to White Mango Scale Damage}

The yield of any crop can be affected by different either insect pest or disease. Currently in the study area the newly emerged and the most devastating insect pest observed attacking mango plant was white mango scale. Plants infested by white mango scale can be physically differentiated from uninfected plants. Fruits attacked by this insect had also seriously affected in quality and quantity. Data collected from the respondents showed that mango yield after the pest attack (white mango scale) was highly reduced quantity. The survey indicated that in the study area before white mango scale attack five to six 


\section{Temesgen Fita}

mango fruits (approximately $1 \mathrm{~kg}$ ) were sold for one birr. Currently in the study area due to less produce of mango fruit one single fruit of mango was sold more than one birr. Observations taken from market (gulit gebeya) also showed that most of mango fruits on sale were affected. One can observe clearly that the color of infested mango fruit was conspicuous with pink blemishes. These
Sci. Technol. Arts Res. J., July-Sep 2014, 3(3): 01-10

blemishes downgrade the fruit quality and have at the maximum two days shelf life; the affected mango fruits rotted and were unfit for use. Data obtained from The survey result (Table 3 ) showed that in the infested districts mango yield obtained before and after white mango scale (WMS) emergence showed high significant differences $(P<0.0001)$.

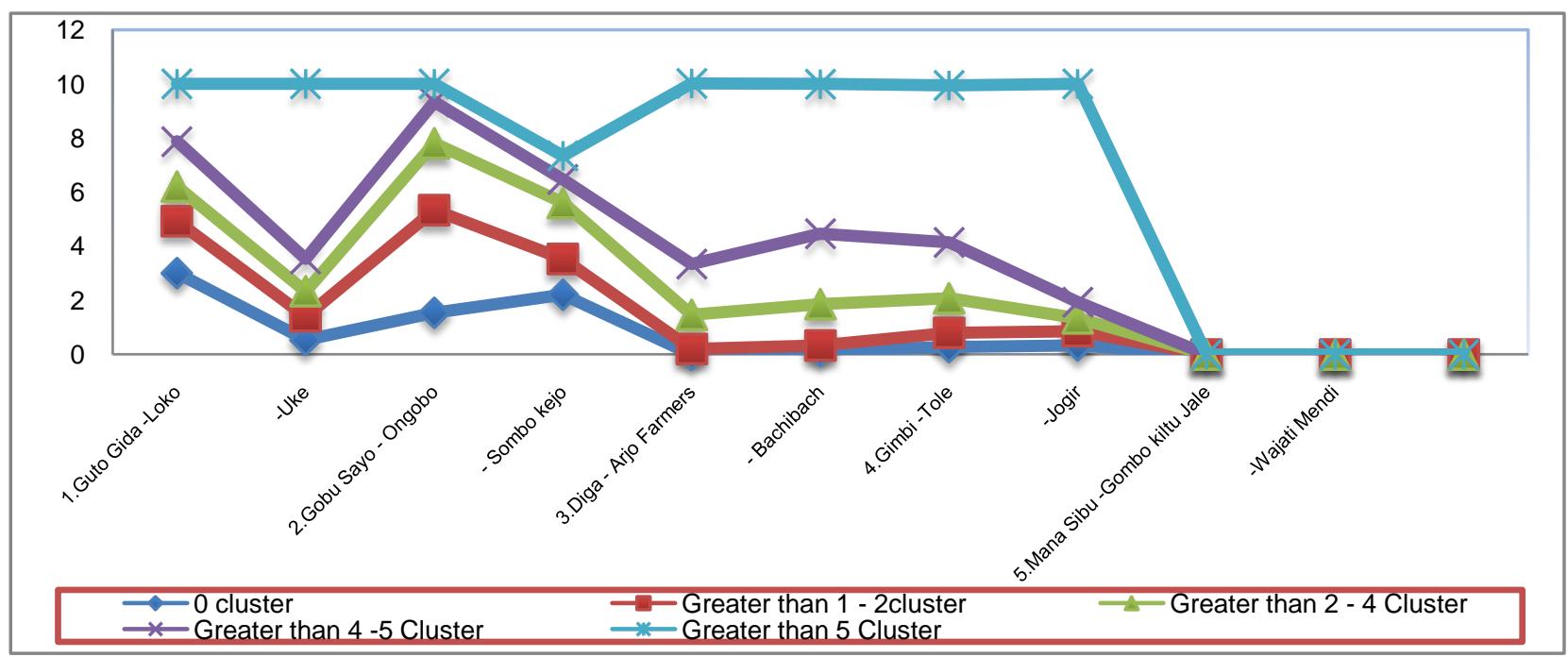

Figure 8: White mango scale cluster formation which show severity of the pest in East and West Wollega

Table 3: Yield comparison between districts before and after WMS emergence

\begin{tabular}{lcccccc}
\hline & \multicolumn{9}{c}{ Variable } & \multirow{2}{*}{ F-value } & \multirow{2}{*}{$\boldsymbol{P}$-Value } \\
\cline { 2 - 4 } \multicolumn{1}{c}{ Source } & \multicolumn{2}{c}{ Before WMS Emergence } & After WMS Emergence & & \\
\cline { 2 - 5 } & $\mathbf{N}$ & Mean(SE) & $\mathbf{N}$ & Mean(SE) & & \\
\hline Districts & & & & & & \\
Guto Gida & 24 & $2.96(0.41)$ & 24 & $1.84(0.60)$ & & \\
Gobu Sayo & 24 & $2.51(0.42)$ & 24 & $0.58(0.30)$ & & \\
Diga & 24 & $2.88(0.20)$ & 24 & $0.56(0.16)$ & & \\
Gimbi & 24 & $2.57(0.50)$ & 24 & $0.49(0.20)$ & & \\
Mana Sibu & 24 & $1.18(0.22)$ & 24 & $1.13(0.19)$ & & \\
\hline
\end{tabular}

\section{White Mango Scale Management Practices by Growers \\ Farmers Management Practices with Indigenous Knowledge \\ A few mango growers with their indigenous knowledge} started practicing cultural control methods like pruning, smoking and site clearing. A few of them practice pruning of heavily infested twigs and dense branches to eliminate infestations when infestations are on limited parts of the plant. Observations given by mango growers, who practice pruning and smoking, showed that pruning increases scale mortality as a result of heat exposure and mango smoking which reduce insect population drastically and improve fruit setting. The farmers smoke under mango plant using fallen mango leaves, grasses, weeds and animal dung within the mango tree area to produce a good amount of smoke which chases insects away from the tree.

Data obtained from the survey showed that from the total respondents $25(20.8 \%)$ of the farmers practiced pruning, $2(1.7 \%)$ practiced smoking and $2(1.7 \%)$ practice site clearing (Figure 9).

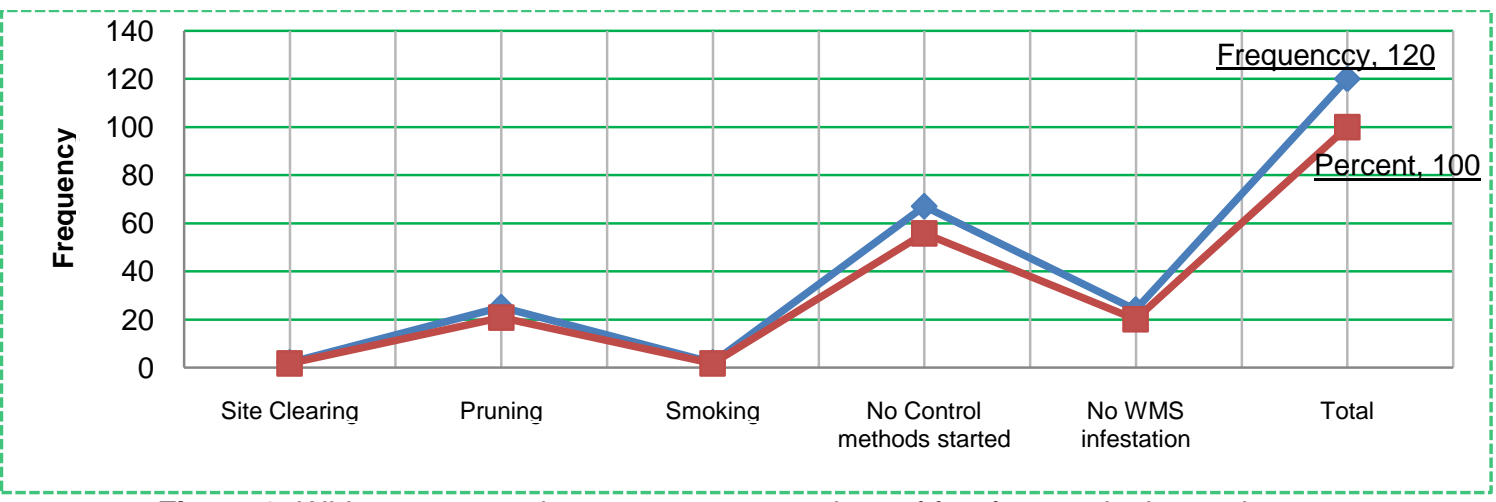

Figure 9: White mango scale management practices of few farmers in the study area 
Temesgen Fita

\section{White Mango Scale Management Practices at Green Focus Ethiopia LTD}

Green Focus Ethiopia LTD is found at Loko Adminstrative kebele, Guto Gida district, owning around 2276 ha of land from which 1185 ha is under mango production with six cultivars. Information obtained from Green Focus Mango Farm, indicated that white mango scale insect infestation was observed in the early 2008 and since then the farm started management practices such as application of broad spectrum synthetic chemical insecticides (organo phosphates) and using tractor mounted sprayers and manual spray methods.

The farm sprays Diaznon and Dimethoate chemicals two times a year before flower setting and after harvest. The farm also practice opening of mango canopies (pruning) and mulching with savannah grass. With such continuous management practices at Green Focus Farm, the pest distribution and severity status was reduced when compared to small growers' farms, but still the farm does have the problem of the insect pest. The different methods used to control insect population should be integrated by a strategy addressed towards greater protection of the cultures with respect to ecological, toxicological and economic principles. The agro ecologic area of Green Focus LTD plantation is hot and low land
Sci. Technol. Arts Res. J., July-Sep 2014, 3(3): 01-10

area having an average altitude of $1384 \mathrm{~m}$ and average minimum temperature of $26-34^{\circ} \mathrm{C}$. During the survey it was seen that spraying was carried throughout day time and the type of spray practiced by the daily workers did not completely cover the infested plants. From such type of spray one can simply understand that chemicals sprayed at mid day can simply evaporate. This type of chemical spray can create pest resistance. Complete spray coverage have infested plants (such as the underside of leaves) and knowing time of spray is needed to have good control.

Thorough spray coverage is especially critical when treating species of armored scales like white mango scale, as these scales are generally less susceptible to pesticides than soft scales.

There were six mango varieties planted at Green Focus Mango Farm namely, Alphonso, Keit, Tommy Atkins, Kent, Apple mango and Dodo. During the survey, information obtained from the farm indicated that the most affected mango variety was Alphonso and this variety was late maturing when compared to other varieties. Alphonso is among the new varieties of mango recently introduced from India in 2001/2002 by Green Focus Ethiopia to East Wollega, Guto Gida district, Loko village.

Table 4: Mango varieties planted in Green Focus Ethiopia LTD Farm and the source of introduction

\begin{tabular}{|c|c|c|c|c|}
\hline Mango Variety & $\begin{array}{c}\text { Year of } \\
\text { Introduction }\end{array}$ & $\begin{array}{l}\text { Source of } \\
\text { Seedlings }\end{array}$ & $\begin{array}{c}\text { Area under } \\
\text { Plantation (ha) }\end{array}$ & $\begin{array}{c}\text { Year of } 1^{\text {st }} \\
\text { Harvest }\end{array}$ \\
\hline Alphanso & $2001 / 2002$ & India & 247 & Not yet \\
\hline Keit & 2002 & UAAIE & 226 & 2007 \\
\hline Kent & 2002 & UAAIE & 376 & 2007 \\
\hline Tommy Atkins & 2002 & UAAIE & 314 & 2007 \\
\hline Apple & 2005 & MARC & 15 & Not yet \\
\hline Dodo & 2006 & UAAIE & 7 & Not yet \\
\hline Total & & & 1185 & \\
\hline
\end{tabular}

From Table 4 it can be seen that Alphonso was planted earlier than the other varieties but the yield was not yet harvested. It was observed that at the plantation site from six varieties of mango grown in the farm, Alphonso was most infested by white mango scale.

\section{CONCLUSIONS}

White mango scale is a new insect pest for the locality and even for the country. This research was initiated and field survey was conducted in East and West Wollega zones of Oromiya Regional State during 2012 crop season to study the status of white mango scale, $A$. tubercularis i.e., its distribution, prevalence and farmers' management practices. The distribution and severity status of white mango scale in mango orchards of the farmers was studied in five districts of the two zones: Guto Gida, Gobu Sayo and Diga districts of East Wollega and Gimbi and Mana Sibu districts of West Wollega Zone.

The study revealed that from the sampled five districts, white mango scale reached and infested all mango growing kebeles of the four districts of Guto Gida, Diga, Gobu Sayo and Gimbi districts except Mana Sibu. Within one year duration the pest moved several $\mathrm{km}$ from the place of its original infestation, Loko kebele (Guto Gida district). Data obtained using GPS and computed by GIS soft ware showed that the maximum air distance covered by white mango scale was $67 \mathrm{~km}$ to the West (Gimbi district- Jogir kebele), on the way from Nekemte to
Asossa, and $58 \mathrm{~km}$ to the East (Gobu Sayo districtSombo Kejo kebele), on the way Nekemte to Finfine.

Even though the leaves, twigs and the fruits of mango plant were attacked by white mango scale, for easy counting rating was done by counting the clusters they form on the leaves to study the population status of white mango scale. The survey revealed that clusters of white mango scale formed per leafes per mango showed high significant differences $(P<0.0001)$ between sampled districts with the mean value of 4.44 . Similarly, data computed from the survey showed that in both zones and the five districts, mango yield obtained before and after white mango scale (WMS) emergence had high significant difference. From the results it was concluded that Gimbi district was the most highly infested district and Gobu Sayo had less severity when compared to the other districts of the study area.

From the current survey it was concluded that white mango scale is becoming the most important limiting factor for mango production in western Ethiopia. Most of the smallholder growers were not aware of this invasive pest. Data obtained from the study areas showed that out of the sampled 120 respondents $74(61.67 \%)$ did not know the name and type of the mentioned insect pest. Only respondents nearby Guto Gida district have a little information about this insect pest. 


\section{Temesgen Fita}

Until this survey was carried out no significant control method was practiced by the nearby agricultural institutions and the farmers. A few farmers with their indigenous knowledge started practicing some cultural control methods like pruning, smoking and site clearing. A few of them practice pruning of heavily infested twigs and dense branches to eliminate infestations when infestations are on limited parts of the plant.

Observations from the survey showed that the pest causes premature drop of leaves, dieback of twigs and branches, stunting and distortion of the fruit, and premature fruit drop. Fruits attacked by this insect had also seriously affected in quality and quantity. The dispersal rate is alarming indicating that within a short period of time the pest can invade the whole of western Ethiopia particularly Wollega zones. Hence, due attention should be given for this insect pest, so that ecologically friendly management options will be made available for the mango growers in that part of the country in particular and Ethiopia in general.

\section{ACKNOWLEDGEMENTS}

I gratefully acknowledge the immense knowledge and insightful guidance of my adviser Dr. Emana Getu and I would like to express my gratitude to Wollega Universiy, for providing me additional financial support for the completion of my research work. I would like extend my gratitude to Ms. Beyenech Besirat, Head of East Wollega zone Water Resource and Mineral Development and to Mr. Teshome Gemeda, Head of East Wollega Zone Food Security, Disaster Preventions and Preparedness Office (FSDPP) for providing me with logistics during the process of data collection.

\section{REFERANCES}

Beniam Teshome. (2010). Thesis on Effect of Processing on some Quality attributes of mango (Mangifera indica) fruit, Science in Chemical Engineering (Food Engineering). Graduate Studies of Addis Ababa University.

Blackburn, V.L. and Miller, D.R. (1984). Pests not known to occur in the U.S. or of limited distribution, no. 44: Black
Sci. Technol. Arts Res. J., July-Sep 2014, 3(3): 01-10 Parlatoria Scale, pp. 1-13. USDA APHIS PPQ, Beltsville, MD.

Bob Williams., Jocelyn E. Eusebio., Hernani G. Golez., Oscar S. Opina., Ernesto O. Brown., Elda B. Esguerra., David Astridge., Terry Campbell and Les Baxter (2009). Integrated pest management and supply chain improvement for mangoes in the Philippines and Australia. Department of Employment, Economic Development and Innovation (DEEDI), Queensland.

Brown, H.H., Darwin, E. (1992). Monitoring for Common Insect Pests of Mango. Agnote, Agdex No.622, ISSN No 0157-8243.

CSA. (2009). Annual report, Central Statistical Authority. Addis Ababa, Ethiopia.

Greathead, D.J. (1990). Crawler behaviour and dispersal, pp. 305-308. In: D. Rosen [ed.], Armored scale insects. Their biology, natural enemies and control. World Crop Pests Volume 4A. Elsevie Scientific Publishers, Amsterdam.

Greathead, D.J. (1997). Ecology: Crawler behaviour and dispersal, pp. 339-342. In: Ben- Dov Y. and Hodgson, C.J. [eds.], Soft scale insects: their biology, natural enemies and control. Elsevier Scientific Publishers, Amsterdam.

Jackson, T.H., Agegnehu Sisson, W., Bruncko, P., Heussier, F. Proctor., Semu-Nigus Hailemariam., Schall, R., Zimmermann, A. (1985). A practical Guideline to Horticulture in Ethiopia.

Miller, D.R. and Davidson, J.A. (1990). A list of the armored scale insect pests, pp. 299-306. In: W. Helle [ed.], Armored Scale Insects: their biology, natural enemies, and control, Volume 4B. Elsevier, Amsterdam.

Timothy D. Schowalter. (2006). Insect ecology; an ecosystem approach, United States of America. Geographic Distribution 13: 179-180.

World Agro Forestry Centre (WAFC). (2006). Final report for Improving Productivity and Market Successes (IPMS) for Ethiopian Farmers Project, Addis Ababa. (ICRAF), Nairobi, July 11. Addis Ababa, Mekele and Awassa. 